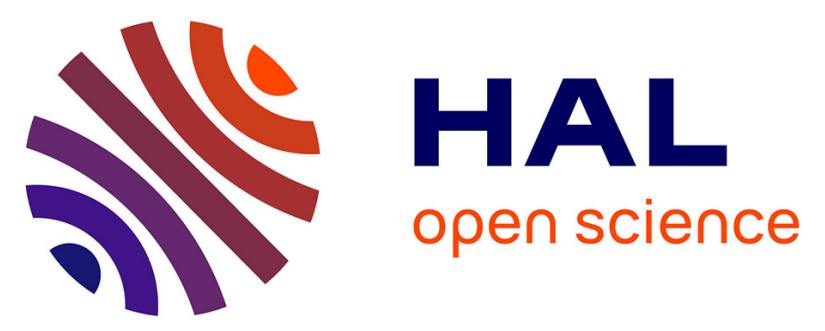

\title{
Delayed hearing loss after microvascular decompression for hemifacial spasm -an unsolved conspiracy of the cochlear apparatus
}

Constantin Tuleasca, Razvan Copaciu, Viviana Aureli, Nozar Aghakhani, Fabrice Parker, Marc Levivier

\section{To cite this version:}

Constantin Tuleasca, Razvan Copaciu, Viviana Aureli, Nozar Aghakhani, Fabrice Parker, et al.. Delayed hearing loss after microvascular decompression for hemifacial spasm -an unsolved conspiracy of the cochlear apparatus. Acta Neurochirurgica, 2019, 161 (8), pp.1599-1601. 10.1007/s00701-01903957-7 . hal-02179272

\section{HAL Id: hal-02179272 \\ https://hal.sorbonne-universite.fr/hal-02179272}

Submitted on 10 Jul 2019

HAL is a multi-disciplinary open access archive for the deposit and dissemination of scientific research documents, whether they are published or not. The documents may come from teaching and research institutions in France or abroad, or from public or private research centers.
L'archive ouverte pluridisciplinaire HAL, est destinée au dépôt et à la diffusion de documents scientifiques de niveau recherche, publiés ou non, émanant des établissements d'enseignement et de recherche français ou étrangers, des laboratoires publics ou privés. 


\section{Delayed hearing loss after microvascular decompression for hemifacial spasm - an unsolved conspiracy of the cochlear apparatus}

Constantin Tuleasca*1,2,3,4,5,6, MD-PhD, Razvan Copaciu ${ }^{* 1}$, MD, Viviana Aureli ${ }^{1,3}$, MD, Nozar Aghakhani ${ }^{1}, \mathrm{MD}, \mathrm{PhD}$, Fabrice Parker ${ }^{1}, \mathrm{MD}, \mathrm{PhD}$ AND Marc Levivier ${ }^{3,6}, \mathrm{MD}$, PhD, IFAANS

${ }^{1}$ Assistance Publique-Hôpitaux de Paris, Hôpitaux Universitaires Paris-Sud, Centre Hospitalier Universitaire Bicêtre, Service de Neurochirurgie, Paris, France; ${ }^{2}$ Sorbonne Université, Faculté de Médecine; ${ }^{3}$ Centre Hospitalier Universitaire Vaudois (CHUV), Neurosurgery Service and Gamma Knife Center, Lausanne, Switzerland; ${ }^{4}$ Medical Image Analysis Laboratory (MIAL) and Department of Radiology-Center of Biomedical Imaging (CIBM), Centre Hospitalier Universitaire Vaudois, Lausanne, Switzerland; ${ }^{5}$ Signal Processing Laboratory (LTS 5), École Polytechnique Fédérale de Lausanne (EPFL), Switzerland; ${ }^{6}$ University of Lausanne, Faculty of Biology and Medicine;

*Constantin Tuleasca and Razvan Copaciu equally contributed as first author

\section{Corresponding author:}

Constantin Tuleasca, MD-PhD, Assistance Publique-Hôpitaux de Paris, Hôpitaux Universitaires ParisSud, Centre Hospitalier Universitaire Bicêtre, Service de Neurochirurgie, Paris, France; Sorbonne Université, Faculté de Médecine; Centre Hospitalier Universitaire Vaudois, Neurosurgery Service and Gamma Knife Center, Rue du Bugnon 44-46, BH-08, CH-1011, Lausanne, Switzerland; Tel: +41-21-314-26-02; Fax: +41-21-314-11-99; e-mail: constantin.tuleasca@gmail.com 


\section{Dear Editor,}

We read with great interest the recent article by Lee et al.[6], regarding delayed ipsilateral hearing loss (median 22 days) after microvascular decompression (MVD) using a retrosigmoid approach for hemifacial spasm (HFS). High-dose corticosteroid treatment was instituted, with further complete recovery after a median time of 45 days. Interestingly, the inter-peak latency of waves I-III in the brainstem auditory evoked potentials (BAEP) were prolonged during the surgery, but recovered within a short time.

An important aspect to clarify, in our opinion, is whether the BAEP abnormalities were found in other cases that did not experience delayed ipsilateral hearing loss. As the authors operated on a large cohort, their particular findings for the 5 patients experiencing such late complication would be even stronger and more relevant. Further evidence on this aspect has been reported in series with contralateral hearing loss after MVD for HFS. Interestingly, while this is extremely rare, the "pathognomonic" sign was also the contralateral delayed inter-peak latencies of the BAEPs. The intraoperative monitoring of the BAEP is once again stressed, as a mean for eventual anticipation of such events. The use of BAEPs during MVD may warn surgeons of cochlear nerve damage intraoperatively by following the latency of wave 5 , which corresponds to the brainstem auditory pathways from the cochlear nucleus to the inferior colliculus[8].

With regards to the possible etiologies, although still unclear after several (although small) published series, should be expanded to some more plausible causes. Lee et al.[6] nicely cited the stretching of the $\mathrm{VIII}^{\text {th }}$ nerve during cerebellar retraction, direct mechanical trauma or further ischemic changes due to the injury of the labyrinthine artery. In our opinion, tissue scaring, as advocated by Janetta itself in a paper by Kuchta et al.[5], could be responsible for this late complication and should be evoked. In fact, if the pia is missing, the unprotected $\mathrm{VIII}^{\text {th }}$ cranial nerve might become subject to electrical or chemical insult, with further change in the conduction velocity of different nerve fibers. Fuse et al.[2] had also shared this theory of a scar tissue, due to the manipulation of the meninges. This would explain the gradual and progressive hearing decline. Other causes could include progressive atrophy of the auditory nerve[2], new direct neurovascular compression, brainstem shift or edema or even labyrinthine fluid imbalance due to CSF release[7].

One should also remind the controversy whether these patients could benefit from a complete hearing recovery or not. As this further impacts the patient's quality of life, it does deserves further attention. Lee et al.[6] nicely propose a high-dose corticosteroid treatment, which seems to attain its desired effect, after variable lapse of time. There is evidence here, although in a small sample size that even in cases with sudden deterioration as delayed as one month after surgery this type of pharmacological treatment could be also of high benefit. Moreover, the applied treatment -although considered empiric- should address what one would presume to be the cause. Shall this cause be tissue scaring (as we consider), corticosteroid is certainly the most appropriate. Other causes, such as infarct of the ipsilateral inferior colliculus documented on postoperative MRI, should benefit from other means, such as intravenous heparinization.

An open question is whether minimally invasive approaches would allow for fewer complications in the future. Historically, Peter Janetta pioneered the MVD in the setting of trigeminal neuralgia. Several months later, he had the great intuition that HFS is most probably acting through the same disease process, in what we call today the " cranial nerve hyperactivity disorders ». He further applied this to the patient, which became cured. After enduring the skepticism of the elders of his time, several years latter his legacy has been formerly recognized as one of the most important discoveries in the neurosurgical field[3]. More recently, MVD for hemifacial spasm has also been described endoscopically[1], which is considered both safe and feasible[4]. Whether this minimally invasive approach would allow avoiding delayed ipsilateral hearing loss remains to be discussed by further series.

In conclusion, the article of Lee et al.[6] adds to the limited evidence of the ipsilateral delayed hearing loss and its potential causes after MVD for HFS. In our opinion, tissue scaring 
and further delayed local inflammation is the responsible cause and corticosteroid treatment addresses this etiology, with further reversibility of the symptoms. BAEP and their respective changes during surgery should draw attention to a more careful follow-up of these patients.

The unsolved conspiracy of the cochlear apparatus will continue to fascinate the field of functional neurosurgery in the context of this recent and nice paper. We postulate that modern neuroimaging techniques (e.g. structural MRI), including detailed fiber tracking by more refined diffusion tensor imaging in the future, or high filed 7 or 14 T MRI enhancing vascular anatomy, would help in the future for a better comprehension and further enhance therapeutic means towards a better care of our patients.

Figure 1: Artistic representation of a neurovascular conflict at the level of the $\mathrm{VII}^{\text {th }}$ nerve. Are further illustrating other anatomical structures, considered as relevant in the context.

Acknowledgments: Constantin Tuleasca and the authors acknowledge the nice contribution of Mia Calin, for providing the artistic figure accompanying this letter. We are mostly grateful.

\section{Compliance with Ethical Standards:}

Funding: Lausanne University Hospital and University of Lausanne.

Conflict of interest: All authors certify that they have no affiliations, with or involvement in any organization or entity with any financial interest (such as honoraria; educational grants; participation in speakers' bureaus; membership, employment, consultancies, stock ownership, or other equity interest; and expert testimony or patent-licensing arrangements), or non-financial interest (such as personal or professional relationships, affiliations, knowledge or beliefs) in the subject matter or materials discussed in this manuscript.

Ethics approval: for this type of letter, no ethical committee approval is necessary 


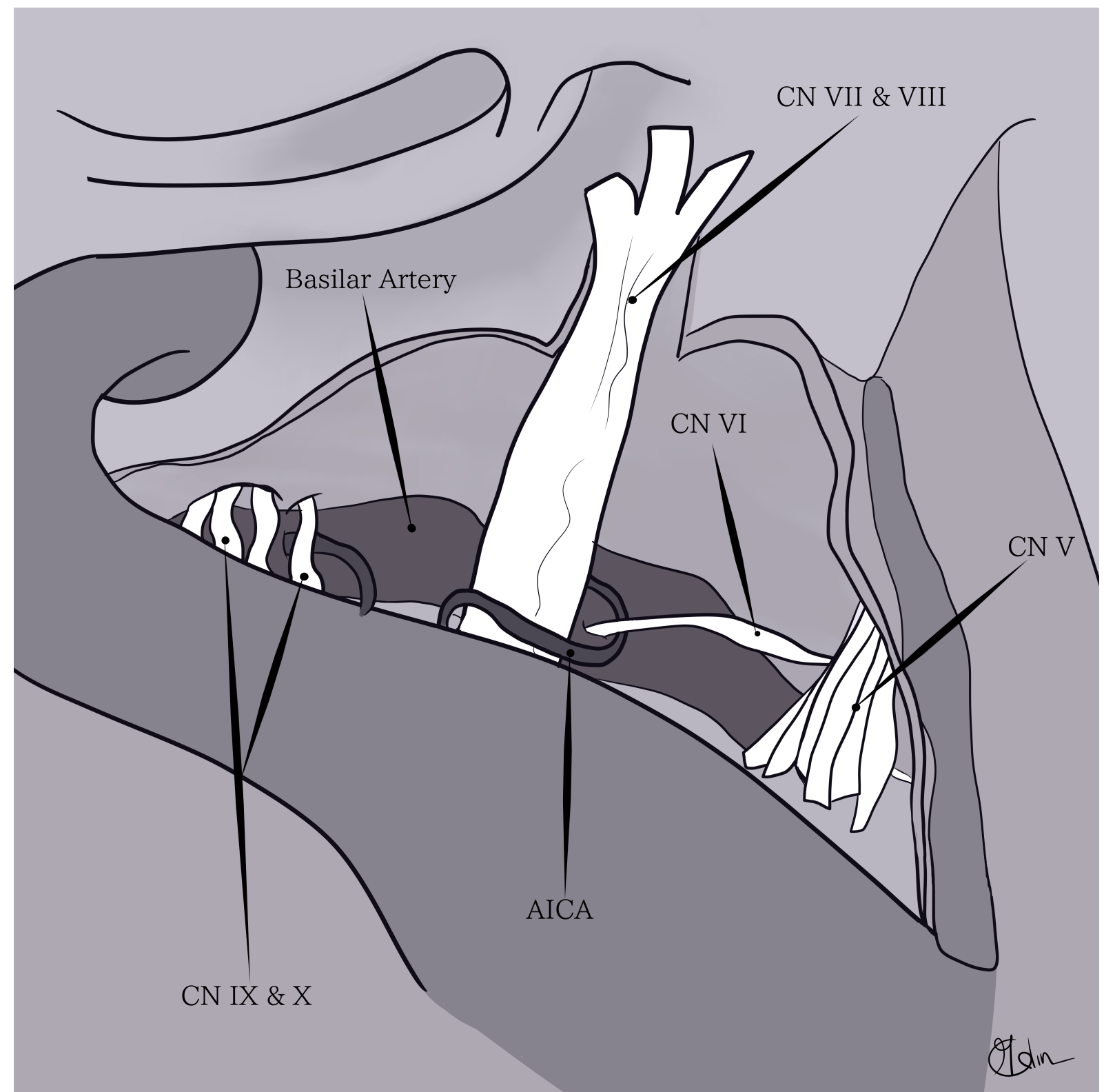




\section{References}

1. Flanders TM, Blue R, Roberts S, McShane BJ, Wilent B, Tambi V, Petrov D, Lee JYK (2018) Fully endoscopic microvascular decompression for hemifacial spasm. Journal of neurosurgery:1-7

2. $\quad$ Fuse T, Moller MB (1996) Delayed and progressive hearing loss after microvascular decompression of cranial nerves. The Annals of otology, rhinology, and laryngology 105:158-161

3. Kaufmann AM, Price AV (2019) A history of the Jannetta procedure. Journal of neurosurgery:1-8

4. Komatsu F, Imai M, Matsumae M (2018) How I do it: endoscopic microvascular decompression for hemifacial spasm associated with the vertebral artery. Acta neurochirurgica 160:157-159

5. Kuchta J, Moller AR, Wedekind C, Jannetta PJ (1998) Delayed hearing loss after microvascular decompression of the trigeminal nerve. Acta neurochirurgica 140:94-97

6. Lee MH, Lee S, Park SK, Lee JA, Park K (2019) Delayed hearing loss after microvascular decompression for hemifacial spasm. Acta neurochirurgica 161:503-508 7. McDonnell DE, Jabbari B, Spinella G, Mueller HG, Klara PM (1990) Delayed hearing loss after neurovascular decompression. Neurosurgery 27:997-1003

8. Strauss C, Naraghi R, Bischoff B, Huk WJ, Romstock J (2000) Contralateral hearing loss as an effect of venous congestion at the ipsilateral inferior colliculus after microvascular decompression: report of a case. Journal of neurology, neurosurgery, and psychiatry 69:679-682 